\title{
触 New Disease Reports \\ First report of potato blackleg caused by Pectobacterium carotovorum subsp. brasiliensis in the Netherlands
}

\author{
L. Nunes Leite ${ }^{1,2}$, E.G. de Haan ${ }^{3}$, M. Krijger ${ }^{1}$, P. Kastelein ${ }^{1}$, P.S. van der Zouwen ${ }^{1}$, G.W. van den Bovenkamp ${ }^{3}$, N.D. \\ Tebaldi $^{2}$ and J.M. van der Wolf ${ }^{1 *}$ \\ ${ }^{1}$ Plant Research International, P.O. Box 69, 6700 AB, Wageningen, The Netherlands; ${ }^{2}$ Universidade Federal de Uberlândia, \\ PO Box 593, 38400-902, Uberlândia, MG, Brazil ; ${ }^{3}$ Nederlandse Algemene Keuringsdienst-Randweg 14, 8304 AS \\ Emmeloord, The Netherlands
}

*E-mail: jan.vanderwolf@wur.nl

Received: 25 Nov 2013. Published: 08 Jun 2014. Keywords: Multilocus sequence analysis, bacterial disease

Potato blackleg and stem rot are caused by various soft rot coliforms belonging to the genera Pectobacterium and Dickeya (van der Wolf \& De Boer, 2007). In Europe, D. solani, D. dianthicola, $P$. atrosepticum and $P$. wasabiae are the main causative agents of the diseases. Recently, in the Netherlands, blackleg diseased plants were found in seed lots produced in different parts of the country, which were positive in a PCR assay for $P$. carotovorum subsp. brasiliensis (Pcb; Duarte et al., 2004) indicating that Pcb had caused the disease. It was estimated that in 2012, Pcb was responsible for approximately 10 percent of blackleg incidence.

Double-layer crystal violet pectate (DL-CVP) medium (Helias et al., 2012) was used to isolate pectinolytic bacteria from the stems of blackleg affected plants. Eleven isolates derived from ten seed lots, positive in the Pcb-specific PCR (Duarte et al., 2004), were characterised with multilocus sequence analysis (MLSA) using sequences of $a c n A, \operatorname{gapA}, i c d A, m d h$, $m t l D, p g i$ and proA (Panda et al., 2012) (GenBank Accession Nos. KJ576801-KJ576810, KJ596350-KJ596399, KJ608062-KJ608071). The phylogenetic analysis was done by constructing a maximum likelihood tree using sequences of reference strains $P$. atrosepticum, P. wasabiae, P.c. subsp. carotovorum, P.c. subsp. odororiferum, P. betavasculorum and Dickeya paradisiaca, derived from GenBank, for comparison (Fig. 1). The MLSA confirmed the identity of the Pcb strains. The Dutch strains clustered together in a homogeneous branch, which also showed that these strains were highly similar. Strains were motile, able to reduce sucrose and to grow at $39^{\circ} \mathrm{C}$, resistant to erythromycin, and unable to ferment lactose according to the procedures described by Hayman et al. (1998). Two Pcb isolates were tested for virulence in a field experiment in the Netherlands in 2013. Two months after planting vacuum-infiltrated seed tubers, a high percentage of the plants (more than 30\%) showed typical symptoms, whereas water-treated plants remained disease-free (Fig. 2). The pathogen was re-isolated from the diseased plants and identified as Pcb using MLSA. This is the first time Pcb is described as a potato blackleg-causing agent in the Netherlands, although a strain of Pcb isolated from potato in the Netherlands has been found in a culture collection before (De Boer $e t$ al.,
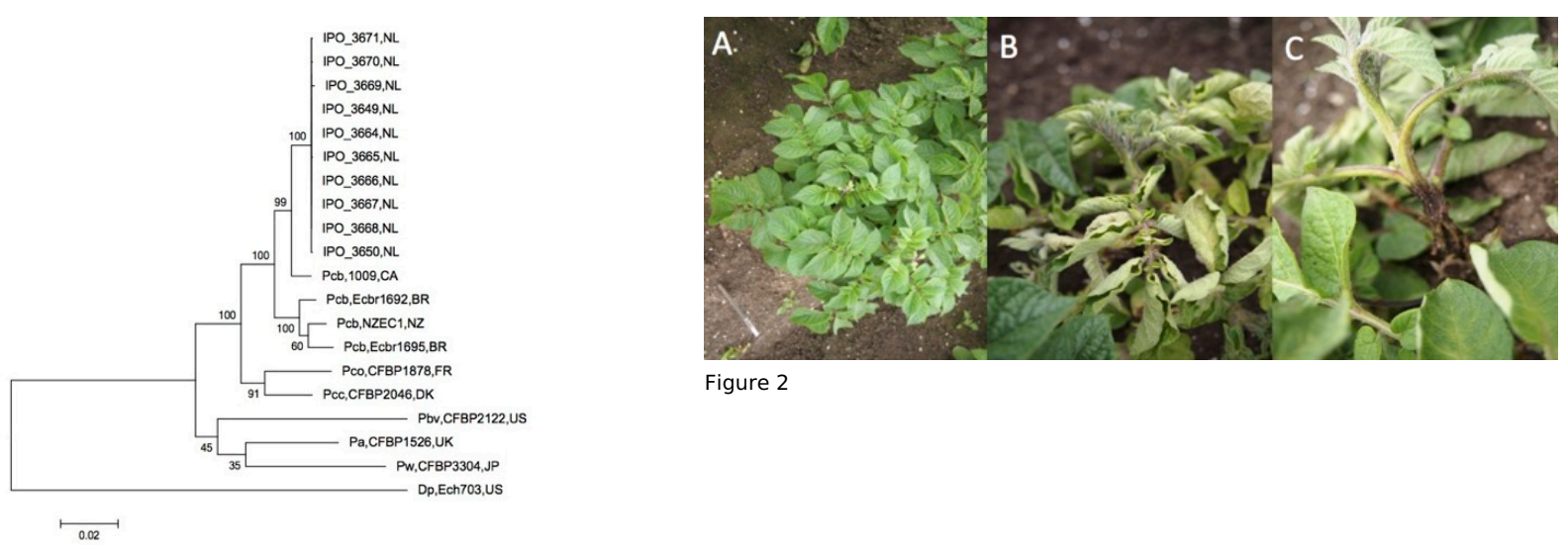

Figure 2

\section{Acknowledgements}

We acknowledge financial support from the Brazilian Program Science without Borders ( $\mathrm{CNPq})$ and the Dutch Ministry of Economic Affairs (program BO-06).

\section{References}

De Boer SH, Li X, Ward LJ, 2012. Pectobacterium spp. associated with bacterial stem rot syndrome of potato in Canada. Phytopathology 102, 937-947. http://dx.doi.org/10.1094/PHYTO-04-12-0083-R

Duarte V, De Boer SH, Ward LJ, de Oliveira AMR, 2004. Characterization of atypical Erwinia carotovora strains causing blackleg of potato in Brazil. Journal of Applied Microbiology 96, 535-545. http://dx.doi.org/10.1111/j.1365-2672.2004.02173.x

Hélias V, Hamon P, Huchet E, Wolf JVD, Andrivon D, 2012. Two new effective semiselective crystal violet pectate media for isolation of Pectobacterium and Dickeya. Plant Pathology 61, 339-345. http://dx.doi.org/10.1111/j.1365-3059.2011.02508.x

Hyman LJ, Toth IK, Pérombelon MCM, 1998. Isolation and identification. In: Perombelon MCM, van der Wolf JM, eds. Methods for the detection and quantification of Erwinia carotovora subsp. atroseptica on potatoes. (Occasional Publication No. 10). Dundee: Scottish Crop Research Institute, 60-65.

Panda P, Fiers MAWJ, Armstrong K, Pitman AR, 2012. First report of blackleg and soft rot of potato caused by Pectobacterium carotovorum subsp. brasiliensis in New Zealand. New Disease Reports 26, 15. http://dx.doi.org/10.5197/j.2044-0588.2012.026.015

Van der Wolf JM, De Boer SH, 2007. Bacterial pathogens of potato. In: Vreugdenhil D, ed. Potato Biology and Biotechnology: Advances and Perspectives. Delft, The Netherlands: Elsevier, 595-617.

Figure 1

To cite this report: Nunes Leite L, de Haan EG, Krijger M, Kastelein P, van der Zouwen PS, van den Bovenkamp GW, Tebaldi ND, van der Wolf JM, 2014. First report of potato blackleg caused by Pectobacterium carotovorum subsp. brasiliensis in the Netherlands. New Disease Reports 29, 24. http://dx.doi.org/10.5197/j.2044-0588.2014.029.024 